\title{
DOES RISK TO ONESELF INCREASE THE CARE OWED TO OTHERS? LAW AND ECONOMICS IN CONFLICT
}

\author{
ROBERT COOTER and ARIEL PORAT*
}

\begin{abstract}
As applied by courts, the Hand Rule balances the injurer's burden of precaution and the victims' reduction in risk. In this application, risk to oneself does not increase the duty owed to others. Economists, however, use the Hand Rule to minimize social costs, which requires balancing the burden of precaution against the reduction in risk to everyone. For economists, risk to oneself counts in determining the duty owed to others. In cases where precaution reduces joint risk (risk to oneself and others), the usual legal interpretation underestimates the reduction in risk relative to the economic interpretation, often by 50 percent. The consequence is a lower standard of legal care than required to minimize social costs. Judges should reconceptualize the Hand Rule so that risk to oneself increases the care owed to others.
\end{abstract}

$\mathbf{M}$ ANY scholars celebrate the acceptance of the Hand Rule by American courts as aligning positive law with economic efficiency. By analyzing the following example, we will show the persistence of a fundamental misalignment:

Example 1. Upon getting into his car, John discovers that the buckle on his seat belt is broken. Buckling it is impossible. No statute requires drivers to wear seat belts. The speed limit is $\mathbf{3 0}$ miles per hour. Time is very valuable to John this morning, so he decides to drive unbuckled. John drives 30 miles per hour, his car skids, and he hits Tony's parked car. If John had driven 25 miles per hour, then he would have avoided hitting Tony's car. Considering John's risk to himself and John's risk to Tony's car, the reasonable speed to drive was 25 miles per hour. Considering only John's risk

* Robert Cooter is the Herman F. Selvin Professor of Law at the University of California, Berkeley. Ariel Porat is Visiting Professor of Law at the University of California, Berkeley, and Professor of Law at Tel Aviv University. We received helpful comments from William Landes, Steve Sugarman, Omri Yadlin, an anonymous reviewer, and participants in the Berkeley Law and Economics Seminar.

[Journal of Legal Studies, vol. XXIX (January 2000)]

(C) 2000 by The University of Chicago. All rights reserved. 0047-2530/2000/2901-0002\$01.50 
to Tony's car, the reasonable speed to drive was 30 miles per hour. The rule of law is negligence. In a suit for damages by Tony, should the court find John liable?

We will show that positive law considers the injurer's risk to others and not to himself. In conventional legal applications of the Hand Rule, courts balance the burden of precaution to the injurer and the risk of harm to the victim. In this example, the court would not admit evidence on the broken seat belt. Risk to the injurer is treated as irrelevant to his legal liability. Considering only the risk to others in this example, driving 30 miles per hour is reasonable, and John is not liable.

Unlike positive law, however, economic efficiency takes account of risks to everyone affected by the act in question. In this example, John's speed and the broken seat belt affect the risk to John. Considering the risk to everyone, driving 30 miles per hour is unreasonable, and John is liable. Liability provides an incentive for John to slow down to 25 miles per hour. Compared to judges, economists have a more general understanding of the Hand Rule, which requires minimizing social costs by balancing the burden of precaution to the injurer and the risk of harm to everyone.

The problem illustrated by example 1 arises whenever (1) the injurer can reduce harm to himself and others at a cost to himself and (2) the law applies a sanction by comparing the injurer's cost of reducing the harm and the resulting benefit to the victim. In such circumstances, omitting the injurer's possible harm to himself causes courts to set the legal standard of care too low. This problem afflicts all negligence rules in the law of torts, including simple negligence, negligence with a defense of contributory negligence, strict liability with a defense of contributory negligence, and comparative negligence. This problem also afflicts other areas of law besides negligence law, such as nuisance law, although this paper focuses exclusively on the law of negligence. The problem, however, does not afflict areas of law that determine liability without comparing the costs and benefits of precaution. In most cases, a rule of strict liability determines liability without such a comparison. ${ }^{1}$

We propose that courts reconceptualize negligence in order to take account of risk to everyone. To be specific, courts should interpret the injurer's burden of care in the Hand Rule as "net burden." By net burden

\footnotetext{
${ }^{1}$ There are exceptions, as in some design-defect cases. A manufacturer is strictly liable for harms to consumers caused by the defective design of a product. The test for a defective design may involve balancing the manufacturer's cost of an alternative design and the resulting reduction in accidents to consumers. In such a case, the problem of inefficiency identified in this paper arises whenever a safer design reduces risk to the consumer and the manufacturer.
} 
we mean the injurer's cost of care minus the resulting reduction in the injurer's risk. By focusing on the net burden, judges can align positive law with economic efficiency.

Now we turn to a related example in order to illustrate a mistake that is easily made when minimizing social costs. The second example is the same as the first except the seat belt is not broken. We change the facts in this way so that the injurer can take a precaution that reduces the risk to himself without affecting the risk to others. Buckling the seat belt in example 2 reduces the risk to John without affecting the risk to Tony, whereas slowing down reduces the risk to John and Tony.

Example 2. John is in a hurry, and he carelessly does not buckle his seat belt when he gets into his car. No statute requires drivers to wear seat belts, but, considering John's risk to himself, John is unreasonable not to buckle his seat belt. The speed limit is 30 miles per hour. Time is very valuable to John, so he drives 30 miles per hour, his car skids, and he hits Tony's parked car. If John had driven 25 miles per hour, then he would have avoided hitting Tony's car. Given the unbuckled seat belt and considering John's risk to himself and Tony's car, the reasonable speed to drive was 25 miles per hour. Considering only the risk to Tony's car, the reasonable speed to drive was 30 miles per hour. If the seat belt had been buckled, and considering John's risk to himself and Tony's car, then the reasonable speed to drive would have been 30 miles per hour. The rule of law is negligence. In a suit for damages by Tony, should the court find John liable?

Applying conventional causation principles to example 2, a court would find John not liable. The reasonable behavior for John in example 2 is to buckle his seat belt and drive fast. If, contrary to fact, John had buckled his seat belt, then he would not have driven any slower than he actually drove. But for the unbuckled seat belt, the same accident would have occurred to Tony's car. As a consequence, John's unreasonable behavior was not the "but-for cause" of Tony's harm. A judge applying conventional causation principles would conclude that the unbuckled seat belt did not cause the injury, so John is not liable.

An economist would typically reach the same conclusion by different reasons. Buckling or unbuckling the driver's seat belt has no external consequences. Regardless of the liability rule, the driver internalizes all the benefits and costs of buckling his seat belt. Even without liability, selfinterest compels John to buckle his seat belt in example 2. To minimize social costs, John should buckle his seat belt and drive 30 miles per hour. ${ }^{2}$

${ }^{2}$ The actual consequences of wearing seat belts on driving speed are estimated in Sam Peltzman, The Effects of Automobile Safety Regulation, 83 J. Pol. Econ. 677 (1975). 
Even without liability for driving 30 miles per hour, John has incentives to achieve the "first-best" outcome.

The law could give additional incentives for drivers to buckle their seat belts by holding them negligent for not slowing down when driving unbuckled. Additional incentives raise costs beyond the level of perfect internalization. The additional incentives prompt the driver to buckle his seat belt, not to slow down. Economists typically see no advantage in imposing liability beyond the point that already internalizes social costs. When selfinterest already compels socially efficient behavior, economists typically fear that additional liability will distort incentives. In any case, John's failure to buckle was a lapse in rationality, and economists typically do not analyze lapses in rationality. (The development of a theory of lapses would refine economic analysis and possibly modify its conclusions. $)^{3}$ The standard economic model concludes that John is not liable.

We explained that the judge who reasons in terms of causation reaches the same conclusion about liability as an economist who reasons in terms of social efficiency. However, a judge who attempts to minimize social costs is likely to make an error in applying the Hand Rule. The mistake arises from a false comparison between example 1 and example 2 . In the first example, John does not buckle his seat belt because he cannot. In the second example, John does not buckle his seat belt because he is unreasonable. If efficiency requires holding John liable in the first example, the judge might reason, then, a fortiori, efficiency must require liability in the second example. This reasoning, however, is wrong. Correct reasoning asserts that minimizing social costs requires the driver in example 1 to slow down, and liability creates an incentive to slow down. In contrast, minimizing social costs in example 2 requires the driver to buckle his seat belt and go fast, and the absence of liability provides this incentive. ${ }^{4}$

\section{A Numerical Example of JoINT Risk}

In economics, "joint product" refers to the unavoidable bundling of two goods in a production process, such as the joint production of wool and

\footnotetext{
${ }^{3}$ The authors are currently working on modeling lapses in tort law. For an attempt to develop such a theory, see Robert Cooter, Lapses, Conflict, and Akrasia in Torts and Crimes: Towards An Economic Theory of the Will, 11 Int'l Rev. L. \& Econ. 149 (1991). Cooter's account of lapses is also found in Robert Cooter, Self-Control and Self-Improvement for the "Bad Man" of Holmes, 78 B.U. L. Rev. 903 (1998); and Robert Cooter, Punitive Damages, Social Norms, and Economic Analysis, 60 Law \& Contemp. Probs. 73 (1997).

${ }^{4}$ Compare William M. Landes \& Richard A. Posner, The Economic Structure of Tort Law 247-49 (1987), in which the authors indicate that sometimes courts ignore other injuries that might have been avoided - in addition to the one before the court-had the defendant taken care. For an argument in that direction, see also Israel Gilead, Tort Law Internalization: The Gap between Private Loss and Social Cost, 17 Int'l Rev. L. \& Econ. 589 (1977).
} 
TABLE 1

Numerical Example of JoINT RISKS SEAT Belt UnBuckled

\begin{tabular}{lcccc}
\hline \hline $\begin{array}{l}\text { Driving } \\
\text { Speed } \\
\text { (m.p.h.) }\end{array}$ & $\begin{array}{c}\text { Cost to } \\
\text { John from } \\
\text { Lost Time }\end{array}$ & $\begin{array}{c}\text { Risk to } \\
\text { Self }\end{array}$ & $\begin{array}{c}\text { Risk to } \\
\text { Others }\end{array}$ & $\begin{array}{c}\text { Social } \\
\text { Costs }\end{array}$ \\
\hline 25 & 100 & 0 & 0 & 100 \\
30 & 0 & 75 & 75 & 150 \\
\hline
\end{tabular}

TABLE 2

NumERICAL EXAMPLE OF JOINT RISKSSeat Belt BuckLed

\begin{tabular}{lcccc}
\hline \hline $\begin{array}{l}\text { Driving } \\
\text { Speed } \\
\text { (m.p.h.) }\end{array}$ & $\begin{array}{c}\text { Cost to } \\
\text { John from } \\
\text { Lost Time }\end{array}$ & $\begin{array}{c}\text { Risk to } \\
\text { Self }\end{array}$ & $\begin{array}{c}\text { Risk to } \\
\text { Others }\end{array}$ & $\begin{array}{c}\text { Social } \\
\text { Costs }\end{array}$ \\
\hline 25 & 100 & 0 & 0 & 100 \\
30 & 0 & 0 & 75 & 75 \\
\hline
\end{tabular}

mutton from raising sheep. In a similar manner, "joint risk" refers to an activity that unavoidably bundles risks to the actor (self-risk) and nonactors (other-risk). For example, driving produces joint risk to the driver and other people. To provide incentives for efficient precaution in such cases, a negligence rule must balance the cost of precaution and the reduction in joint risk.

Table 1 and Table 2, which use numbers to develop example 1 and example 2, respectively, illustrate the difference between an action that reduces joint risk (slowing down) and an action that reduces only self-risk (buckling your seat belt). According to the first column of numbers in Table 1, slowing down from 30 to 25 miles per hour costs John 100 in lost time. If John is unbuckled as in example 1, then slowing down reduces the expected cost of the joint risk to himself and others, each by 75 . Thus if the seat belt is unbuckled, the cost of precaution (100) is less than its social benefit (150), so efficiency requires John to slow down. Since the burden of precaution (100) is less than the reduction in joint risk (150), an economic application of the Hand Rule concludes that the driver should be held liable for going 30 miles per hour. If the driver is held liable for going 30 miles per hour, he clearly minimizes his costs by driving 25 . Thus the economic interpretation of the Hand Rule provides incentives for efficient behavior.

Courts that follow the usual practice of comparing the burden of precau- 
tion and the reduction of risk to others, however, would reach a different result. According to Table 1, the burden of precaution (100) exceeds the risk to others (75), so such a court would presumably find John nonnegligent. If the court finds John nonnegligent, then slowing down from 30 to 25 miles per hour costs him 100 in lost time and saves him 75 in risk to himself, so he will not slow down. Given positive law, self-interest compels John to drive 30 in a situation where efficiency requires him to drive 25 .

Notice that the joint risk is 150 in Table 1, whereas the other-risk is 75 . When joint risk is symmetrical between injurer and victim, as in many collisions, positive law underestimates the benefits of precaution by 50 percent. In asymmetrical accidents, however, positive law underestimates the benefits of precaution by an amount that can vary from 0 percent to much more than 100 percent.

This example considers only two levels of precaution (driving 25 or 30 miles per hour), so precaution is treated as binary. This example illustrates three generalizations about binary precaution. (i) Given binary precaution, the traditional application of the Hand Rule finds "no liability" whenever the burden is more than the reduction in risk to others $(B>o)$. (ii) Given binary precaution and no liability, the injurer takes no precaution when the burden is more than the reduction in risk to himself $(B>s)$. (iii) Minimizing social costs requires taking precaution whenever the burden is less than the sum of the reduction in risk to self and others $(B<s+o)$. In summary, the traditional application of the Hand Rule creates inefficient incentives for the injurer to take no precaution whenever the burden is more than self-risk and also more than other-risk, and the burden is less than the sum of selfrisk and other-risk. If one of these conditions is relaxed, however, the injurer may take efficient precaution even under the traditional Hand Rule. In any case, the economic Hand Rule completely solves this problem.

Instead of being binary, precaution often takes several different values or changes continuously, as with driving speed. Given continuous precaution and some other technical conditions familiar to economists, the traditional Hand Rule inevitably results in setting the standard of precaution too low. The standard is inevitably too low because the marginal cost of a little more precaution, which should be balanced against the marginal benefit to self and others, is balanced only against the marginal benefit to others. With continuous variables, setting the standard of care too low typically results in insufficient precaution by potential injurers. Thus the conditions for the failure of the traditional Hand Rule are simpler and more general when precaution is continuous rather than binary. As in the binary case, the economic Hand Rule completely solves this problem. A mathematical appendix proves these conclusions about the continuous case.

As in example 1, Table 1 assumes that John cannot buckle his seat belt. 
Now we extend the numerical illustration to example 2, where John can buckle his seat belt. Whereas Table 1 shows costs when John drives with his seat belt unbuckled, Table 2 shows costs when John drives with his seat belt buckled. For simplicity, we assume that buckling the seat belt is without cost and completely eliminates the additional risk to the driver from higher speed. Comparing Table 1 and Table 2, social costs fall to their minimum of 75 when John buckles his seat belt and drives fast. Assuming John can buckle his seat belt, this is the first-best outcome. In example 2 , no liability for driving $\mathbf{3 0}$ miles per hour provides an incentive for John to buckle his seat belt and drive fast. To be precise, under no liability, John can drive 30 miles per hour with his seat belt buckled and bear costs of 0 , or John can drive 25 miles per hour unbuckled and bear costs of 100 .

\section{Positive Law CRITIQued}

By ignoring the effect of injurer's precaution on self-risk, American common law systematically fails to analyze accurately the problem of joint risks. The Restatement (Second) of Torts adopts this inefficient approach. Article 291 states: "Where an act is one which a reasonable man would recognize as involving a risk of harm to another, the risk is unreasonable and the act is negligent if the risk is of such magnitude as to outweigh what the law regards as the utility of the act or of the particular manner in which it is done" (emphasis added). Article 293 adds: "In determining the magnitude of the risk for the purpose of determining whether the actor is negligent, the following factors are important: . . . (b) the extent of the chance that the actor's conduct will cause an invasion of any interest of the other or of one of a class of which the other is a member." Risk to oneself is not mentioned in the latter articles of the Restatement. ${ }^{5}$

Under positive negligence law, liability is ascribed to injurers who cause losses by their unreasonable behavior. The Hand Rule, which the Restatement officially recognizes in Articles 291-93, provides an explication of "unreasonable behavior." In the Hand Rule, unreasonableness depends on two variables: the risks the injurer created and the precautions he could have taken to reduce those risks. The formula directs courts to determine

s See also Restatement (Second) of Torts $\S \S 298,300$. While revising this paper for publication, we learned that the problem may be ameliorated soon. The Discussion Draft of the Restatement of the Law Third, Tort: General Principles, promulgated in April 1999, partly corrects what the Second Restatement missed. According to Article 4 of the Draft, harm is one factor that a court should consider in ascertaining whether care is reasonable. The Reporter's Note to the Draft clarifies the text by saying explicitly that risks to others and risks to self are both relevant forms of harm for determining negligence. We believe that explicit use of the language of "joint risk," "self-risk," and "social costs" would further improve the Draft. 
liability by comparing precaution $(B)$ with expected damages $(P L)$. If $B<$ $P L$, then the injurer is found negligent, and if $B>P L$, then he is not found negligent. Under the best interpretation, these variables refer to marginal values. As a consequence, the injurer is considered negligent when his marginal costs of precaution fall short of the marginal reduction in the expected damages. ${ }^{6}$

By its wording, the Hand Rule is not limited to others' risks. It may encompass the actor's risk to himself. Thus the Hand Rule can receive an economic interpretation that encompasses social risks. Judges since Learned Hand, however, have systematically ignored the defendant's risk to himself in applying the rule. Instead, judges systematically define negligence in terms of creating unreasonable risks toward others. ${ }^{\text {? }}$

The complexity of facts obscures this conclusion about the well-known United States v. Carroll Towing Co. case, ${ }^{8}$ which established the Hand Rule among American judges. A prior decision of Judge Hand, Conway v. $O^{\prime}$ Brien, ${ }^{9}$ which was given 7 years earlier and used the same formula without the algebraic terms, is simpler and clearer. In Conway, the plaintiff was injured in a road accident while a passenger in the defendant's car. Under the statute prevailing at the time, the driver was liable toward his guestpassenger only if he had been grossly negligent in causing the accident. The specific question posed by the court was whether or not the defendant's driving was grossly negligent. Judge Hand formulated the standard of care as follows: "The degree of care demanded of a person by an occasion is the resultant of three factors: the likelihood that his conduct will injure oth-

${ }^{6}$ Robert Cooter \& Thomas Ulen, Law and Economics 276-77 (2d ed. 1997).

7 See W. L. Prosser \& W. P. Keeton, Torts (5th ed. 1984). "[Negligence] has been defined as ... conduct 'which falls below the standard established by law for the protection of others against unreasonable risk of harm." " Id. $\S 31$, at 169. "The essence of negligence is . . behavior which should be recognized as involving unreasonable danger to others." Id. "Negligence as it is commonly understood is conduct which creates an undue risk of harm to others. Contributory negligence is conduct which involves an undue risk of harm to the actor himself." Id. § 65, at 453. "The standard [of reasonable care] is breached by action that creates a risk that no reasonable person would impose upon others. . . Through the notion of risk, what one person does can be regarded from the standpoint of what another person might suffer.' Ernest Weinrib, The Idea of Private Law 147 (1995). "The allegation in a negligence action is basically that the defendant paid insufficient attention to the interests of others in deciding how to behave, and has pursued his or her own objectives at the risk of injuring other people or damaging their property.' P. Cane, Atiyah's Accidents, Compensation and the Law 39-40 (1993). 'People may drive their cars at a 'reasonable' speed because the gain to them and the public from being allowed so to drive is at least worth the risk of the loss such driving may cause; but people are not allowed to drive at an 'excessive' speed because the additional gain that it brings to them does not outweigh the additional risk that it imposes on others." Id. at 39.

${ }^{8}$ United States v. Carroll Towing Co., 159 F.2d 169 (1947).

${ }^{9}$ Conway v. O’Brian, 111 F.2d 611 (1940). 
ers, taken with the seriousness of the injury if it happens, and balanced against the interest which he must sacrifice to avoid the risk." 10

After applying this test, Judge Hand concluded that the defendant was not grossly negligent. " Judge Hand seems unaware that minimizing social costs in these circumstances involves balancing the burden of precaution against the reduction in self-risk and other-risk. Had Judge Hand weighed the driver's self-imposed risk together with passengers' risks, he might have reached a different conclusion.

Like Judge Hand, courts applying the Hand Rule in subsequent cases fail to understand the nature of joint risks. A case decided by Judge Richard Posner, Brotherhood Shipping Co., Ltd. v. St. Paul Fire \& Marine Insurance Co., ${ }^{12}$ illustrates this point. In this case, a shipowner brought a suit against the city of Milwaukee for damages resulting from a collision between the ship and the slip in which it was berthed at the time of the accident. The slip was also damaged, and therefore a counterclaim was brought by the city to recover its damages from the shipowner. Since this case appealed a motion for summary judgment dismissing the shipowner's claim, the court had to decide whether "viewing the evidence ... as favorable to the shipowner ... [the court] can say that no reasonable trier of fact could conclude that the city had been even a little bit negligent." 13

The design and maintenance of the slip presumably affects the risk to ships (other-risk) and the slip (self-risk). An economic application of the Hand Rule should balance the city's burden of precaution and the resulting reduction in joint risk. The risk to the slip was large, as indicated by the damages that actually materialized. When Judge Posner compared the burden of precaution that the city could have taken to the resulting reduction in risk, his discussion does not mention the risk to the slip. ${ }^{14}$ Perhaps Judge Posner was unaware of the potential importance of self-risk in this case, or perhaps he responded to the arguments of attorneys who never raised the issue of self-risk. In any event, after discussing other-risk and not self-risk,

${ }^{10}$ Id. at 612 (emphasis added).

11 The U.S. Supreme Court thought otherwise. The case was reversed, and the question of gross negligence was retried. See Conway v. O'Brein, 312 U.S. 492 (1941).

${ }^{12}$ Brotherhood Shipping Co., Ltd. v. St. Paul Fire \& Marine Insurance Co., 985 F.2d 323 (1993).

${ }^{13}$ Id. at 324.

14 "Evaluating these facts with the aid of the Hand formula, we note first that $\mathrm{L}$ in the formula - the magnitude or gravity of the loss that an accident that the precautions the defendant failed to take would have averted could be expected to inflict-was substantial. The ships that dock at the Port of Milwaukee are expensive machines carrying expensive goods. Moreover, an accident to such a ship, even while the ship is berthed, could endanger human life. . . . The ship could have sunk, like the E. M. Ford, in which event the loss might easily have exceeded \$5 millon." Id. at 329. 
Judge Posner concluded that the city's alleged negligence must be tried in the district court. If the district court were to decide the case by ignoring the risk to the city's slip, it would presumably set the legal standard too low for economic efficiency.

\section{The Net Burden Approach}

As explained, courts show no awareness that minimizing social cost requires the legal standard of care to respond to the injurer's risk to himself. If judges reflected upon the effect of self-risk on the legal standard or if lawyers argued this point to judges, then perhaps the practice of courts would change. Adjusting the burden in the Hand Rule provides a natural way to make the change. We state abstractly the nature of the adjustment and then discuss a case where the judge seems to make this adjustment.

As explained, the economic Hand Rule balances the burden of precaution to the injurer and the reduction in expected accident costs to the injurer and the victim, which we write as (BURDEN) < (REDUCTION IN SELF-RISK + OTHER-RISK). The formula can also be written as (BURDEN - REDUCTION IN SELF-RISK) < (REDUCTION IN OTHER-RISK). The term "BURDEN - REDUCTION IN SELF-RISK" subtracts the injurer's benefit from the injurer's burden, thus giving the net burden. The net burden interpretation of the Hand Rule fully encompasses social costs.

According to the net burden interpretation, the Hand Rule concerns the net costs of precaution, not the gross costs. If precautions benefited the injurer in any way, those benefits are subtracted from the gross costs of precaution, and only the difference is compared to the expected damages of others. If we apply this approach to our previous example in Table 1 , the court would define John's net precaution costs as $100-75=25$. His precaution costs are only 25 according to this reasoning, whereas this precaution creates benefits of 75 to others; so failing to take precaution is negligent. Thus the net burden approach creates incentives for efficient behavior.

With rare exceptions, however, courts follow the gross burden approach when interpreting the Hand Rule. Courts sometimes mention that precaution reduces the benefit of the activity to the injurer. For example, driving slower may reduce the benefit from driving. When more precaution reduces the benefit from the activity, courts may take this reduction into account when setting the negligence standard. ${ }^{15}$ Courts, however, do not mention that precaution increases the safety of the activity for the injurer.

15 "It is thus fundamental that the standard of conduct which is the basis of the law of negligence is usually determined upon a risk benefit form of analysis: by balancing the risk, 
A recent federal district court decision, Johnson v. City of Milwaukee, ${ }^{16}$ departs from this pattern by following a special version of the net burden approach. In Johnson, the court used the Hand Rule to determine whether an off-duty police officer who shot a suspect while trying to arrest him infringed the victim's Fourth Amendment right against unreasonable search and seizures. The court specifically considered the question of whether reasonableness required the off-duty police officer to wait until on-duty help arrived instead of using force immediately. The court concluded that the police officer behaved unreasonably under the circumstances. The court reasoned, inter alia, that had the police officer waited for backup, he could have reduced the risks to the suspect, the community in general, and himself. In the court's words,

Brown [the police officer] could have taken precautions which would have increased both Johnson's safety and his own. ...

In this case the possibility of harm to individuals or the community if officer Brown had waited for back-up, used verbal control or ordered Johnson to the ground before frisking him was non-existent. If Brown had waited for back-up or put Johnson on the ground, his own safety and Johnson's would have been enhanced....

The discharge of a firearm could have caused great harm-even death-to the officer or the suspect. In sum, a reasonable jury considering the officer's conduct in light of the Hand formula could conclude that the burden of precautions was less than the probability of an accident times the potential loss and that Brown's actions were therefore unreasonable. ${ }^{17}$

When a police officer arrests a dangerous criminal, the risk to the officer and the criminal connect in an obvious way. In the typical case, the officer can reduce the risk to himself by increasing the risk to the criminal. When the officer's risk and the criminal's risk trade off, an increase in the officer's own risk is the burden of reducing the criminal's risk. When an increase in self-risk is the burden of precaution, any use of the Hand Rule inevitably focuses on the net burden. The court in Johnson inevitably focused on the net burden because the central question was whether or not a trade-off existed between self-risk and other-risk.

\section{The Pervasiveness of Joint Risks}

The following four paradigmatic examples, based on real cases, illustrate some forms of joint risk that pervade law:

in the light of the social value of the interest threatened, and the probability and extent of the harm, against the value of the interest which the actor is seeking to protect, and the expedience of the course pursued." Prosser, supra note $7, \S 31$, at 173.

${ }^{16}$ Johnson v. City of Milwaukee, 41 F. Supp. 2d 917 (1999).

${ }^{17}$ Id. (emphasis added). 
1. Collisions. In any road accident, the injurer's precaution affects the risk to himself and others. Ignoring self-risk leads to suboptimal standards of care. This holds true in other collisions besides road accidents, such as marine accidents, as illustrated by the preceding discussion of the Brotherhood case. ${ }^{18}$

2. The Failure to Protect Others from Criminals. A criminal attacks and injures an employee in the workplace. The victim sues her employer for failing to protect her from criminals. In considering the question of liability under negligence law, courts should weigh the employer's precautions against the reduction in everyone's risk at work. Everyone's risk includes the risk to the property and persons of the employees and the employer. To illustrate concretely, a bank robbery risks harm to people and the loss of a lot of the bank's money, whereas robbery of a grocery store risks harm to people and the loss of relatively little money. Therefore, economic efficiency requires the bank to take more precaution against robberies than the grocery store.$^{19}$ In general, a company's duty of care to protect against criminals should increase to the extent that criminals impose risks on the company as well as others.

3. Maintenance of Property. A guest in a house who falls on the stairs sues the homeowner. In considering the homeowner's liability under negligence law, courts should consider the cost and benefits of maintaining the stairs. The benefits include the reduction in risk to guests and the owner. Insofar as the owner uses the stairs more frequently than guests, the reduction in risk to the owner should affect the legal standard of care owed to guests more than the risk to guests. In any case, taking the owner's risks into account will increase the precautions required by the law. ${ }^{20}$

4. Abatement of a Nuisance. A neighbor seeks to enjoin an adjacent property owner who makes smoke, sparks, noise, odors, effluent, or floods. If an injunction is issued, the property owner will have to abate the nuisance or abandon the activity causing it. Following Spur v. Del Webb ${ }^{21}$ and

${ }^{18}$ For two examples of collision cases in which courts probably ignored the risk to the injurer and could have reached different outcomes if they had not done so, see Barnes $v$. Charles W. Thames, Fireman's Fund Insurance Co., 578 So. 2d 1155 (1991); Blair v. Tynes, 610 So. 2d 956 (1992).

${ }^{19}$ For cases of failure to protect others from criminals in which courts probably ignored the risk to the defendant, see, for example, McCarty v. Pheasant Run, Inc., 826 F.2d 1554 (1987); Madden v. C \& K Barbecue Carryout, Inc., 758 S.W. 2d 59 (1988); Doe v. Dominion Bank of Washington, N.A., 963 F.2d 1552 (1992).

${ }^{20}$ For cases involving maintaining property and similar acts in which courts probably ignored the risk to the defendant, see, for example, Lirette v. State Farm Insurance Co., 581 So. 2d 265 (1991); Eaton v. McLain, 891 S.W. 2d 587 (1994).

${ }^{21}$ Spur v. Del Webb, 494 P.2d 700 (1972). 
Boomer v. Atlantic Cement, ${ }^{22}$ the court balances the benefits and costs of abating, abandoning, or allowing the harm to continue. Besides benefiting the victim, abating will presumably reduce the smoke, sparks, noise, bad odors, effluent, or floods that the injurer afflicts upon himself. In weighing the benefits of abating, the court must consider the benefits to injurer and victims.

\section{CONCLUSION}

As interpreted by courts, the Hand Rule, which formulates and critiques the duty of care that people owe to others, balances the injurer's burden of precaution and the victims' reduction in risk. Economists, however, use the Hand Rule to minimize total social costs, which requires balancing the burden of precaution against the reduction in risk to everyone. In cases where precaution reduces joint risk (risk to oneself and others), the legal interpretation underestimates the reduction in risk relative to the economic interpretation, often by 50 percent. The consequence is a lower legal standard of care than required to minimize social costs.

We recommend that courts reconceptualize the Hand Rule so that risk to oneself increases the care owed to others. In order to take account of selfrisk, courts must determine its extent. In the absence of a counter suit, courts do not ordinarily inquire into the extent that the accident exposed the defendant to risk. The application of the economic Hand Rule requires changing this practice. Perhaps the easiest way to make the change is to interpret the injurer's burden of care as the net burden, by which we mean the injurer's burden of care minus the reduction in the injurer's risk.

If courts make this change, they will create a new problem. If courts consider defendant's self-risk, defendants will have an incentive to understate it. By understating self-risk, defendants can hope to lower the legal standard of care applied to their behavior. Courts have means to correct this bias, but even if the correction fails, understating self-risk leads to better results than the current practice of computing the legal standard as if self-risk were zero.

Besides applying the Hand Rule, courts also determine negligence by applying a community standard of care. An unanswered question is whether or not community standards take account of joint risk as required for efficiency or whether communities, like courts, restrict attention to other-risk. Answering this question requires a theory of the evolution of social norms, which we will not attempt to construct here.

Critics of the economic analysis of law, especially philosophers of law,

${ }^{22}$ Boomer v. Atlantic Cement, 257 N.E.2d 870 (1970). 
may offer a variety of reasons to dismiss our conclusions. ${ }^{23} \mathrm{~A}$ careful consideration of our arguments, however, may convince philosophers of law to support our conclusions. Most moral theories recognize the relevance of the injurer's interests when determining his moral responsibility toward others. Any moral theory recognizing the injurer's burden as relevant to his moral responsibility must acknowledge that reducing self-risk reduces the injurer's real burden, which we call the net burden. As a result, our argument refines the explanation of the injurer's burden. Philosophers who accept the relevance of the injurer's burden to the legal standard should welcome our clarification of its real extent.

\section{APPENDIX}

According to Guido Calabresi's original prescription, tort law should minimize the sum of the costs of accidents and avoiding accidents. ${ }^{24}$ This formulation implicitly takes account of risks to everyone affected by the act in question. Judge Hand's formulation of the Hand Rule in mathematical notation, including the explication of it by Richard Posner in the first edition of his textbook, ${ }^{25}$ is also consistent with taking everyone's risks into account. In these writings, however, the effect of selfrisk on the standard of care is not discussed explicitly. Early mathematical formulations that compare equilibria for alternative tort rules, such as those of John Brown and Robert Cooter, Lewis Kornhauser, and David Lane, do not capture the effect of self-risk. ${ }^{26}$

Avon Leong and Jennifer $\mathrm{H}$. Arlen eventually addressed the problem of self-risk explicitly. ${ }^{27}$ Leong concluded that a negligence rule would fail to give efficient incentives to victims whose behavior affected the injurer's self-risk, whereas Arlen demonstrated that the possibility of a counter suit would restore efficient incentives for victims' precaution. These papers, however, do not remark on the fact that positive law omits self-risk when using the Hand Rule to determine the legal standard of care.

We will explain our argument using simple mathematics that most closely resemble Arlen's formulation. Let $A_{s}$ denote self-harm, by which we mean the cost of accidental harm to the actor. Let $A_{0}$ denote other-harm, by which we mean the cost of accidental harm to people other than the actor. Let $x$ denote the actor's precaution that reduces the probability $(p)$ of an accident, where $w_{x}$ indicates the price of $x ; p$ is a decreasing function of $x$. Thus $p(x)\left(A_{s}+A_{o}\right)$ indicates expected accident costs.

${ }^{23}$ Our thanks to Sam Scheffler for helping us to formulate these remarks on philosophy.

${ }^{24}$ See Guido Calabresi, The Costs of Accidents: A Legal and Economic Analysis 26 (1970).

${ }^{25}$ Richard Posner, The Economic Analysis of Law 69 (1st ed. 1972).

${ }^{26}$ For example, John Brown, Toward an Economic Theory of Liability, 2 J. Legal Stud. 323 (1973); Robert Cooter, Lewis Kornhauser, \& David Lane, Liability Rules, Limited Information and the Role of Precedent, 10 Bell J. Econ. 366 (1979).

${ }^{27}$ Avon Leong, Liability Rules When Injurers as Well as Victims Suffer Losses, 9 Int'l Rev. L. \& Econ. 105 (1989); Jennifer H. Arlen, Re-examining Liability Rules When Injurers as Well as Victims Suffer Losses, 10 Int'l Rev. L. \& Econ. 233 (1990). 


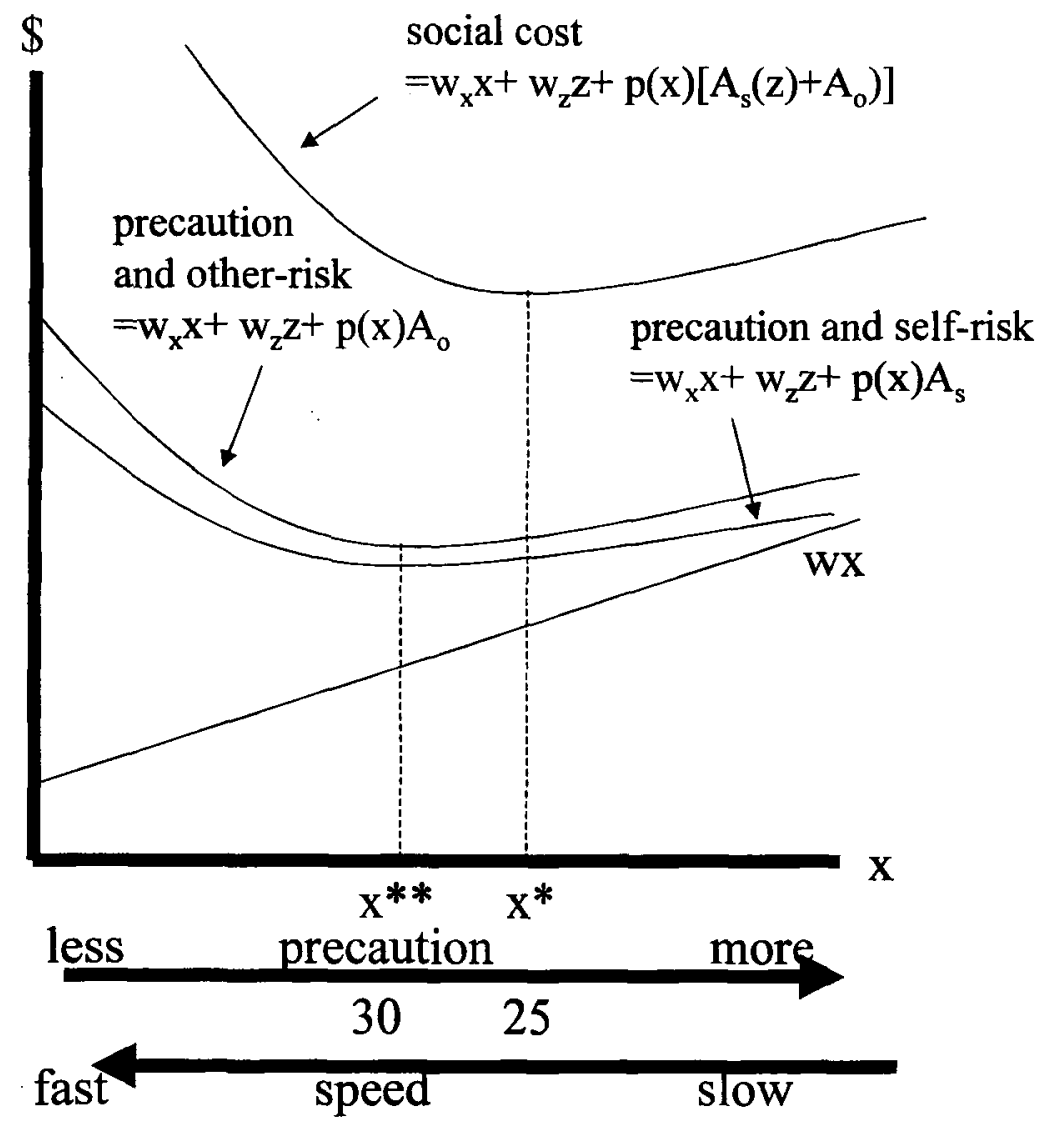

Figure 1.- Joint costs versus other costs

Note that precaution $x$ reduces risk $p$ of losing $A_{s}$ for oneself and $A_{o}$ for others. Thus $x$ reduces joint risk.

To illustrate in terms of example $1, A_{s}$ is accidental harm to John, $A_{o}$ is accidental harm to Tony's car, $p$ is the probability of an accident, $x$ is the inverse of driving speed, and $w_{x}$ is the value of the driver's time.

Now we consider a form of precaution that reduces risk to the injurer and not to the victim. Let $z$ denote the actor's precaution that reduces $A_{s}$ at a cost of $w_{z}$, and $A_{s}$ is a decreasing function of $z$, which we write $A_{s}(z)$. To illustrate from example $2, z$ is the buckling of the seat belt and $w_{z}$ is the cost of this effort. Social costs are given by the following formula:

$$
\mathrm{SC}=w_{x} x+p(x)\left(A_{s}(z)+A_{o}\right)+w_{z} z
$$

As depicted in Figure 1, social costs reach their minimum at the point $x^{*}$ where the marginal cost of precaution equals the marginal reduction in social risk: 


$$
w_{x} \leq-p^{\prime}\left(A_{s}+A_{o}\right) .
$$

Social efficiency also requires choosing $z$ to satisfy the equation

$$
w_{z} \leq-p A_{s}^{\prime} .
$$

Now we relate the social optimum to the language of the Hand Rule under its economic interpretation. In the Hand Rule, $w_{x}$ corresponds to the burden and $p^{\prime}\left(A_{s}\right.$ $+A_{o}$ ) corresponds to the benefit. Efficiency requires balancing the marginal burden $w_{x}$ and the marginal reduction in risk to self and others $p^{\prime}\left(A_{s}+A_{o}\right)$.

Unlike the economic application of the Hand Rule, positive law removes risk to self from consideration. If risk to self is removed from the social cost formula, then $A_{s}$ drops out and the minimum occurs at $x^{* *}$, where

$$
w_{x} \leq-p^{\prime}\left(A_{o}\right) .
$$

Under the Hand Rule of positive law, the legal standard in Figure 1 is $x^{* *}$.

Under positive law, the injurer chooses $x$ to minimize the sum of the costs of his precaution and expected liability. In terms of Figure 1, positive law creates incentives for the injurer to find the lowest point on the two-piece line

$$
\begin{gathered}
w_{x} x+w_{z} z+p(x)\left(A_{s}+A_{o}\right) \quad \text { for } x<x^{* *} \text { (zone of liability), } \\
w_{x} x+w_{z} z+p(x) A_{s} \quad \text { for } x \geq x^{* *} \text { (zone of no-liability). }
\end{gathered}
$$

In Figure 1, the minimum for the injurer's costs occurs at $x^{* *}$. Thus positive law gives the injurer the incentive to set precaution equal to $x^{* *}$, whereas efficiency requires an increase in precaution to $x^{*}$. 